\title{
SEEDS INOCULATION AND NITROGEN FERTILIZATION FOR COWPEA PRODUCTION ON LATOSOL IN THE WESTERN AMAZON
}

\author{
PRODUTIVIDADE DE FEIJÃO-CAUPI COM INOCULANTE E FONTE MINERAL \\ NITROGENADA EM LATOSSOLO DA AMAZÔNIA OCIDENTAL
}

\author{
Vladis Barreto MOREIRA ${ }^{\mathbf{1}}$ Emmerson Rodrigues de MORAES $^{\mathbf{2}}$; \\ Rafaella Ferreira Batista BERNARDES ${ }^{3}$; Joicy Vitória Miranda PEIXOTO ${ }^{4}$; \\ Brenda Ventura de LIMA
}

1. Graduando em Agronomia, Universidade Estadual de Roaraima - UERR, Rorainópolis, RR, Brazil; 2. Professor, Mestre, Instituto Federal Goiano, Morrinhos, GO, Brazil; 3. Mestre, Universidade Federal de Uberlândia - UFU, Uberlândia, MG, Brazil .rafaellaferreiraagro@gmail.com; 4. Doutoranda, Universidade Federal de Uberlândia - UFU, Uberlândia, MG, Brazil; 5. Técnica Administrativa, mestre, Instituto Federal Goiano, Morrinhos, GO, Brazil.

\begin{abstract}
The cowpea is an important food crop in the North and Northeast regions of Brazil, where the beans are consumed either green or ripe. Yet, considering its socio-economic importance and its tropical origin, cowpea yields are low in those regions, due to inadequate cultivation practices and incorrect soil management. Therefore, the objective of this study was to study the development of cowpea crop inoculated and fertilized with two different nitrogen (N) sources. The experiment was conducted in the municipality of Rorainópolis (RR). The experimental design was randomized blocks with four treatments and five replications. The plant material was 'BRS Guariba' cowpea cultivar, and the treatments were: (i) control (no nitrogen fertilization), (ii) seeds inoculated with Bradyrhizobium elkanii, (iii) urea as $\mathrm{N}$ source $\left(60 \mathrm{~kg} \mathrm{~N} \mathrm{ha}^{-1}\right)$, and (iv) ammonium sulphate as $\mathrm{N}$ source $\left(60 \mathrm{~kg} \mathrm{~N}^{-1}\right)$. The following crop traits were evaluated: foliar macronutrients $(\mathrm{N}, \mathrm{P}, \mathrm{K}, \mathrm{Ca}, \mathrm{Mg}$ and $\mathrm{S})$, green and dry weight of shoots, dry beans per plant, pod yield and bean yield. Urea and ammonium sulphate promoted high accumulation of nutrients in leaves. Ammonium sulphate also stood out regarding productivity traits, thus proving to be a viable $\mathrm{N}$ source for cowpea in the Amazon region. The nodulation with Bradyrhizobium elkanii wasn't efficient to replace the fertilization with nitrogen fertilizers for cowpea BRS Guariba.
\end{abstract}

KEYWORDS: Fertilization. Bradyrhizobium elkanii. Vigna unguiculata.

\section{INTRODUCTION}

The cowpea (Vigna unguiculata) plays a major social and economic role for the population in the North and Northeast regions of Brazil (FREIRE FILHO et al., 2005), where it is the main low-cost protein source and offers various employment opportunities (CHAGAS JUNIOR et al., 2010).

According to the fifth Conab (2016) survey, an estimated cowpea yield in Brazil for the 2015/16 production season was $570 \mathrm{~kg} \mathrm{ha}{ }^{-1}$, and total production $224,900 \mathrm{t}$. In the North, the estimated yield for the same season was $655 \mathrm{~kg} \mathrm{ha}^{-1}$, and total production 2,500 $\mathrm{t}$.

The cowpea is considered a tropical crop, adaptable to soil and weather conditions in the Amazon region, but it does not produce good yields there. Among various factors that contribute to this state, the management of soil fertility, particularly low supply of nitrogen (BRITO et al., 2011), and also the use of low-yielding traditional crops play a major role.

In the Amazon region, one major obstacle for agricultural production is low availability of nitrogen in the soil, which is further aggravated by high mineralization rates of organic matter due to high humidity and temperature (NOVAIS, 2007). Low fertility of soils may lead to incorrect and indiscriminate use of chemical fertilizers by farmers (VALE JÚNIOR et al., 2011). Alternatives, such as sustainable soil management with no-till, minimum tillage, split doses of nitrogen fertilizers, different nitrogen inoculants, and plant coverage may be adopted to diminish these problems (TAGLIAFERRE et al., 2013).

Therefore, due to weather conditions in the Amazon region and physical and chemical characteristics of soils, which are mostly sandy with low fertility, adequate soil fertility management practices-nitrogen in particular-for the cowpea crop are necessary.

Considering the importance of nitrogen fertilization, as well as the environmental and socioeconomic conditions in the region, the objective of this study was to evaluate two fertilizers $\mathrm{N}$ sources and Bradyrhizobium elkani as a seed inoculant for the production of cowpea BRS Guariba.

\section{MATERIAL AND METHODS}

The experiment was carried on the rural property "Alvorada" $\left(01^{\circ} 14 ' 56 " \mathrm{~N}\right.$ and $\left.60^{\circ} 9^{\prime} 02^{\prime \prime W}\right)$, 
located in Rorainópolis, $\mathrm{RR}$, in the southern region of Roraima at an altitude of $80 \mathrm{~m}$, The average annual rainfall in the local is $2,500 \mathrm{~mm}$ and the average annual temperature $25^{\circ} \mathrm{C}$. According to the Köppen-Geige climatic classification, the weather is classified as Af- equatorial, hot and humid. Chemical and physical analysis of soil from layer 0$20 \mathrm{~cm}$ revealed the following characteristics: $\mathrm{pH}$

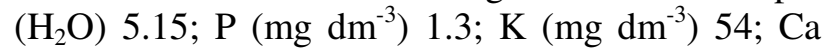
$\left(\mathrm{cmol}_{\mathrm{c}} \mathrm{dm}^{-3}\right) 1.7 ; \mathrm{Mg}\left(\mathrm{cmol}_{\mathrm{c}} \mathrm{dm}^{-3}\right) 0.6 ; \mathrm{Al}\left(\mathrm{cmol}_{\mathrm{c}}\right.$ $\left.\mathrm{dm}^{-3}\right)$ 0.02; $\mathrm{H}+\mathrm{Al}\left(\mathrm{cmol}_{\mathrm{c}} \mathrm{dm}^{-3}\right) 2.54 ; \mathrm{m} \mathrm{( \% )} 1.3 ; \mathrm{V}$ (\%) 49.6; MO (dag kg $\left.{ }^{-1}\right)$ 19.6; sand $\left(\mathrm{g} \mathrm{kg}^{-1}\right)$ 520; silt $\left(\mathrm{g} \mathrm{kg}^{-1}\right) 303$; and clay $\left(\mathrm{g} \mathrm{kg}^{-1}\right)$ 177. The soil was classified as dystrophic yellow latosol.

The experimental design was randomized blocks with four treatments and five replications. The treatments were: control (no nitrogen fertilization), inoculant (Bradyrhizobium elkanii), urea $\left(60 \mathrm{~kg} \mathrm{ha}^{-1} \mathrm{~N}\right)$, and ammonium sulphate $(60 \mathrm{~kg}$ $\mathrm{ha}^{-1} \mathrm{~N}$ ). The plots consisted of four rows, each 5-mlong, 2-m-wide, and $0.5 \mathrm{~m}$ apart. The total area of each plot was $10 \mathrm{~m}^{2}$, on which $4.0 \mathrm{~m}^{2}$ was the experimental area with two central lines, disregarding $0.5 \mathrm{~m}$ from both ends.

Soil, which was left fallow after corn, was prepared before planting by disc harrowing. Soil fertilization $\left(350 \mathrm{~kg} \mathrm{ha}^{-1}\right.$ superphosphate and 66.66 $\mathrm{kg} \mathrm{ha}{ }^{-1}$ potassium chloride) was based on soil analysis, second Embrapa Roraima (2009). Sowing was carried out on September 13, 2012 using a 4row planter and a conventional system with row spacing of $0.5 \mathrm{~m}$ and 12 seeds per meter. Rows were thinned out down to 8 plants per meter, or 160.000 plants $\mathrm{ha}^{-1}, 10$ days after emergence (days after plant emergence).

The plant material was cowpea cultivar BRS Guariba, which is characterized by semi-erect posture, white beans, black hilum, and good adaptability to the conditions in the North regions (GONÇALVES et al., 2009). Cowpea seeds were inoculated with Bradyrhizobium elkanii strain BR 3262 at concentration $10^{8}$ cells g ${ }^{-1}$. Inoculant dosage was $500 \mathrm{~g}$ per $50 \mathrm{~kg}$ of seeds. Inoculation was carried out after wetting the seeds with $6 \mathrm{ml} \mathrm{kg}^{-1}$ of sugar solution (10\% $\left.\mathrm{pv}^{-1}\right)$ (HUNGRIA et al., 2001). Nitrogen sources used in this experiment were urea $(46 \% \mathrm{~N})$ and ammonium sulphate $(20 \% \mathrm{~N}+22 \%$ $\mathrm{S})$. Nitrogen sources used in this experiment were urea $(46 \% \mathrm{~N})$ and ammonium sulphate $(20 \% \mathrm{~N}+$ $22 \%$ S). Nitrogen dose was split into two equal applications, one 12 days after plant emergence and the other 25 days after plant emergence. To compensate for the lack of $S$ in urea, elemental $S$ was applied in 2 equal applications.

The volume of accumulated rainfall between planting and harvest (65-day cycle) was $440 \mathrm{~mm}$. Weed control was done by spraying $50 \mathrm{~g}$ of fenoxaprop-p-ethyl $+50 \mathrm{~g}$ of clethodim per hectare 15 days after plant emergence, and cucurbit beetle and aphids control by spraying $30 \mathrm{~g} \mathrm{ha}^{-1}$ of cypermethrin. Diseases control was not necessary due to low levels of severity.

Macronutrient status was measured in leaves collected in two central lines on each plot at the beginning of flowering 35 days after plant emergence. The third trifoliate leaf of the apical tuft was collected from 30 plants on all plots, according to recommendations by Ambrosano et al. (1997) and metodology according to Malavolta et al. (1997). Also, green pods per plant were counted and collected 45, 49 and 53 days after plant emergence. The first time, the pods were collected from 10 plants chosen at random per plot, later the pods were collected from the same plants. Dry pods were harvested from ten plants chosen at random from two central rows to obtain the number of dry beans per plant 60 days after plant emergence. Beans from 100 pods were also counted. One hundred beans with $20 \%$ humidity were weighed. The yield of dry beans was expressed in $\mathrm{kg} \mathrm{ha}^{-1}$. Ten plants were collected at random during flowering to evaluate dry matter production of shoots $\left(\mathrm{kg} \mathrm{ha}^{-1}\right)$.

The results were submitted to analysis of variance by $\mathrm{F}$ test at $5 \%$ probability. Later, they were compared by Tukey test at 5\% significance using SISVAR 5.3 software (FERREIRA, 2011).

\section{RESULTS AND DISCUSSION}

Accumulation of macronutrients varied depending on $\mathrm{N}$ source (Table 1). Ammonium sulphate caused the highest $\mathrm{N}$ accumulation. Both urea and ammonium sulphate promoted high accumulation of K relative to the control, but didn't differ from B.elkanii. Regarding Mg, all treatments promoted higher accumulation than the control. Also, urea and ammonium sulphate promoted high $\mathrm{S}$ accumulation relative to the inoculant, but didn't differ from the control. For $\mathrm{P}$ and $\mathrm{Ca}$, there wasn't difference among the treatments. 
Table 1. Mean values of nutrient accumulation in cowpea for different $\mathrm{N}$ sources.

\begin{tabular}{|c|c|c|c|c|c|c|}
\hline Nutrient source & Nitrogen & $\begin{array}{l}\text { Phospho } \\
\text { rus }\end{array}$ & $\begin{array}{l}\text { Potassiu } \\
\mathrm{m}\end{array}$ & Calcium & $\begin{array}{l}\text { Magnesiu } \\
\mathrm{m}\end{array}$ & Sulphur \\
\hline & \multicolumn{6}{|c|}{ 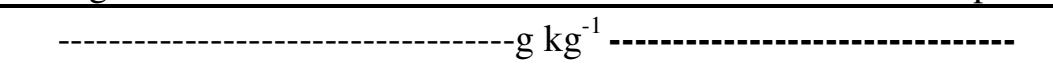 } \\
\hline Urea & $40,78 \mathrm{~b}$ & $2,24 \mathrm{a}$ & $18,92 \mathrm{a}$ & $10,90 \mathrm{a}$ & $2,12 \mathrm{a}$ & $22,58 \mathrm{a}$ \\
\hline Ammonium sulphate & 44,38 a & $2,52 \mathrm{a}$ & $20,84 \mathrm{a}$ & $12,02 \mathrm{a}$ & $2,26 \mathrm{a}$ & $22,64 \mathrm{a}$ \\
\hline Bradyrhizobium elkanii & $37,46 \mathrm{c}$ & $2,60 \mathrm{a}$ & $18,70 \mathrm{ab}$ & $10,86 \mathrm{a}$ & $2,18 \mathrm{a}$ & $14,70 \mathrm{~b}$ \\
\hline Control & $37,66 \mathrm{bc}$ & $2,60 \mathrm{a}$ & $14,76 \mathrm{~b}$ & $11,44 \mathrm{a}$ & $1,82 \mathrm{~b}$ & $19,34 \mathrm{ab}$ \\
\hline $\mathrm{CV}(\%)$ & 4,44 & 8,64 & 12,34 & 9,75 & 7,88 & 14,60 \\
\hline DMS & 3,21 & 0,39 & 4,09 & 1,99 & 0,30 & 5,24 \\
\hline
\end{tabular}

Means followed different letters in the column differ by Tukey test at $5 \%$ propability.

The availability of nutrients for plant uptake depends on various physical, chemical and biological processes. Several mechanisms in the soil and in the plant may influence nutritional composition of the plant, such as ionic interactions, which can be classified as inhibition when the presence of one ion inhibits or decreases the absorption of another ion, or synergism when one ion increases the absorption of another ion.

Data in table 1 show that $\mathrm{N}$ status was higher in the treatment with ammonium sulphate. As this fertilizes contains $\mathrm{S}$, this increase demonstrates the interaction between $\mathrm{N}$ and $\mathrm{S}$. Nitrogen uptake may be affected by the presence of other nutrients, including S. According to Malavolta and Moraes (2007), N and S demonstrate synergism, thus affecting the quality of the final product. In plant physiology, the union of the metabolic pathways of assimilation of $\mathrm{N}$ and $\mathrm{S}$ is represented by the incorporation of sulfide in the O-acetylserine by the OAS-thiol lyase enzyme in the formation of cysteine (CRAWFORD et al., 2000). A nutritional imbalance of these nutrients affects protein synthesis.

Urea was amended with elemental sulfur $\left(S^{0}\right)$ to compensate for $S$ present in ammonium sulphate. However, more $\mathrm{N}$ was found in the treatment with ammonium sulphate. This is probably due to the fact that elemental sulfur is absorbed by plants only after its oxidation to sulphate by means of reactions catalyzed mainly by microorganisms (HOROWITZ; MEURER, 2006). Sulfur is absorbed by plants in the form of $\mathrm{SO}_{4}{ }^{2-}$; therefore, the uptake of $\mathrm{SO}_{4}{ }^{2-}$ by plants from ammonium sulphate might have been higher than elemental sulfur.

In cowpea, $\mathrm{K}$ is extracted and exported in large quantities. Potassium has many functions in the plant, mainly the activation of several enzymatic systems, many of which participate in the processes of photosynthesis and respiration. Deficient plants show slow growth, poorly developed roots, weak and very flexible stems, susceptibility to disease, and poor formation of seeds and fruits which are usually smaller and rather faintly colored (SOUZA et al., 2012 ).

Viana and Kiel (2010), evaluating $\mathrm{N}$ and $\mathrm{K}$ in wheat, reported that high $\mathrm{N}$ doses associated with $\mathrm{K}$ increased dry matter production of shoots. Also, Panaullah et al. (2006), evaluating K uptake in rice and wheat in succession, found that $\mathrm{N}$ fertilization increased $\mathrm{K}$ uptake in wheat. This demonstrates that there is an interaction between $\mathrm{N}$ and $\mathrm{K}$. In this study urea and ammonium sulphate increased $\mathrm{K}$ content relative to the control, but didn't differ from the treatment with seed inoculation.

Variations were observed regarding plant production traits (Table 2). Ammonium sulphate promoted high production of fresh weight of shoots (FWS) relative to the inoculant, but didn't differ from the other treatments. Ammonium sulphate also increased dry weight of shoots (DWS), more than urea and the inoculant; however, the results didn't differ from the control treatment. No difference among the treatments was observed for the number of green pods per plant (GPP) and dry beans per plant (DBP). Pod yield (PY) in treatments with urea and ammonium sulphate was higher than with the inoculant, but didn't differ from the control. And for the bean yield (BY), ammonium sulphate promoted higher production than the inoculant and the control, but didn't differ from urea. 
Table 2. Yield components evaluated in cowpea crop for different treatments with $\mathrm{N}$ fertilization

\begin{tabular}{|c|c|c|c|c|c|c|}
\hline Nutrient source & FWS & DWS & GPP & DBP & PY & BY \\
\hline & \multicolumn{2}{|c|}{-------g plant ${ }^{-1}------$} & \multicolumn{2}{|c|}{--Unit. plant ${ }^{-1}---$} & \multicolumn{2}{|c|}{------kg ha"------ } \\
\hline Urea & $46,9 \mathrm{ab}$ & $6,88 \mathrm{~b}$ & $3,92 \mathrm{a}$ & $48,0 \mathrm{a}$ & $6624,0 \mathrm{a}$ & $872,6 \mathrm{ab}$ \\
\hline Ammonium sulphate & $65,9 \mathrm{a}$ & $9,67 \mathrm{a}$ & $4,46 \mathrm{a}$ & $60,0 \mathrm{a}$ & $6300,0 \mathrm{a}$ & $1064,0 \mathrm{a}$ \\
\hline Bradyrhizobium elkanii & $33,6 \mathrm{~b}$ & $4,93 \mathrm{~b}$ & $3,72 \mathrm{a}$ & $40,0 \mathrm{a}$ & $4920,0 \mathrm{~b}$ & $660,0 \mathrm{~b}$ \\
\hline Control & $45,9 \mathrm{ab}$ & $6,73 \mathrm{ab}$ & $3,92 \mathrm{a}$ & $52,0 \mathrm{a}$ & $5408,0 \mathrm{ab}$ & $650,0 \mathrm{~b}$ \\
\hline $\mathrm{CV}(\%)$ & 29,12 & 29,14 & 14,37 & 29,83 & 12,80 & 20,92 \\
\hline DMS & 25,34 & 3,72 & 1,04 & 26,99 & 1346,4 & 307,42 \\
\hline
\end{tabular}

FWS = fresh weight of shoots; DWS = dry weight of shoots; GPP = number of green pods per plant; DBP = number of dry beans per plant; PY = pod yield; BY = bean yield. Means followed different letters in the column differ by Tukey test at $5 \%$ probability.

These results confirm that ammonium sulphate is an ideal $\mathrm{N}$ source for cowpea in that region, and can replace urea. Nitrogen fertilization of this crop in soil should also be maintained to ensure high yield of beans and pods. Reduced amount of $\mathrm{N}$ (maximum $20 \mathrm{~kg} \mathrm{ha}{ }^{-1}$ ) promoted nodulation and crop yield, according to Xavier et al., 2008.

Cowpea has the ability to establish efficient symbiotic relationship with rhizobia. However, some factors, such as competition with other microorganisms and inhibition by chemicals present in soil, may undermine the effectiveness of inoculants in regions different from their origin (NEVES; RUMJANEK, 1997). Soil pH is one of the main limiting factors for nodulation and nitrogen fixation (HUNGARY AND VARGAS, 2000; RAZA et al., 2001). Some species may tolerate acidity better than others, and this tolerance may vary between strains of the same species (HUNGARY et al., 1997). Bacterial fixation grow in an ideal $\mathrm{pH}$ range between 6.0 and 7.0, and few grow well at $\mathrm{pH}$ below 5.0 (RODRIGUES et al., 2006; Ali et al., 2009). To maximize the contribution of biological nitrogen fixation (BNF) to common bean in acid soils, it is necessary that the strains used in the inoculants be adapted to this condition, competitive and efficient in the infection process. In general, treatment with B. elkanii inoculant did not yield satisfactory results. One of the possible explanations may be low adaptability of the strain used in the inoculation to the environmental conditions of the experiment site, such as the low $\mathrm{pH}$ value in water (5.15), which may have reduce B. elkanii inoculation and fixation.

In general, $B$. elkanii didn't produce satisfactory results. One possible explanation may be low adaptability of the strain to the environmental conditions of the experimental site. The B. elkanii BR 3262 is one of the isolates which have potential for biological nitrogen fixation (BNF). It comes from the Atlantic Forest region, demonstrates excellent adaptability to the region of Piauí Savanah, and interacts very well with BRS Guariba (GUALTER et al., 2007; ZILLI et al., 2006).

BRS Guariba did nodulate; however, the effect wasn't any better than for ammonium sulphate. Therefore, if the goal is to replace chemical fertilizers, a possible solution would be to establish appropriate inoculum density for the region (SILVA JÚNIOR et al., 2014). Another alternative would be to study the behavior of different cowpea inoculated with different strains of nitrogen fixing bacteria in the Amazon region. Similar work for a semi-arid region was carried out by Marinho et al. (2014), in which several inoculated cultivars showed bean yield similar to plants fertilized with urea.

The table 3 presents arrays of simple linear correlations between leaf macronutrient levels, dry matter, and yield components of cowpea. The following correlations were significant and positive: FWS x DWS $\left(\mathrm{r}=0.99^{* *}\right)$, FWS x GPP $(\mathrm{r}=0.94 *)$, DWS x GPP $(r=0.94 *)$ for urea; FWS x DWS $(r=$ $\left.0.99^{* *}\right)$ for ammonium sulphate; FWS x DWS ( $\mathrm{r}=$ $0.99 * *) \mathrm{Mg}$ x S $(\mathrm{r}=0.88 *)$ for B. elkanii; and FWS x DWS $\left(r=0.99^{* *}\right)$ for the control. The correlation between FWS and DWS becomes evident where in dry matter increases with green matter (RODRIGUES et al., 2012). The positive correlation between $\mathrm{Mg}$ x S may be associated with higher levels of aminoacid (cystine, cysteine and methionine), favoring production of chlorophyll, in which Mg is present (NEVES et al., 2008).

However, the following correlations were negative: $\mathrm{P} \times \mathrm{Mg}\left(\mathrm{r}=-0.90^{*}\right), \mathrm{K} \times \mathrm{DBP}(\mathrm{r}=-0.92 *)$, $\mathrm{Ca} \times \mathrm{Mg}\left(\mathrm{r}=-0.95^{*}\right), \mathrm{S} \times \mathrm{BY}\left(\mathrm{r}=-0.96^{* *}\right)$ for urea; $\mathrm{Ca} \times \mathrm{S}\left(\mathrm{r}=-0.92^{*}\right), \mathrm{S} \times \mathrm{PY}\left(\mathrm{r}=-0.90^{*}\right)$ for ammonium sulphate; $\mathrm{N}$ x FWS $\left(\mathrm{r}=-0.98^{* *}\right), \mathrm{N} x$ 
DWS $\left(\mathrm{r}=-0.98^{* *}\right), \mathrm{S} \times \mathrm{DBP}(\mathrm{r}=-0.91 *)$ for $B$. elkanii; and $\mathrm{N} \times \mathrm{PY}(\mathrm{r}=-0.92 *), \mathrm{K} \times \mathrm{Ca}(\mathrm{r}=-$ 0.90*), Ca $\times$ FWS $(r=-0.94 *)$, Ca $x$ DWS $(r=-$ 0.94*) for the control. Magnesium uptake may suffer competition with others cations due to low affinity with binding sites on the plasma membrane (NETO et al., 2014). Pegoraro et al. (2014), studying uptake of nutrients by common bean 36 days after plant emergence, observed high translocation of nutrients from leaves to beans in the following order: $\mathrm{P}>\mathrm{N}>\mathrm{Mg}>\mathrm{S}>\mathrm{K}>\mathrm{Ca}$. Thus, reduction of $\mathrm{P}, \mathrm{K}, \mathrm{Mg}$ and $\mathrm{S}$ may be related to translocation to flowers and fruits when entering the reproductive stage 35 days after plant emergence.

Table 3. Simple linear correlation between nitrogen, phosphorus, potassium, calcium, magnesium and foliar sulfur, fresh weight of shoots (FWS), dry weight of shoots (DWS), green pods per plant (GPP), dry beans per plant (DBP); pod yield (PY); and bean yield (BY) for each treatment, Rorainópolis - RR, 2013.

\begin{tabular}{|c|c|c|c|c|c|c|c|c|c|}
\hline Variables & $\mathrm{Ca}$ & $\mathrm{Mg}$ & $\mathrm{S}$ & FWS & DWS & GPP & DBP & PY & BY \\
\hline \multicolumn{10}{|c|}{ Urea } \\
\hline $\mathrm{P}$ & 0,78 & $-0,90 *$ & $-0,21$ & $\begin{array}{l}-0,44 \\
\end{array}$ & $\begin{array}{l}-0,44 \\
\end{array}$ & $-0,14$ & 0,20 & $-0,01$ & 0,30 \\
\hline K & $-0,23$ & 0,50 & $-0,64$ & $-0,40$ & $-0,40$ & $-0,67$ & $-0,92 *$ & 0,35 & 0,50 \\
\hline $\mathrm{Ca}$ & 1 & $-0,95 *$ & $-0,44$ & $-0,33$ & $-0,33$ & $-0,17$ & $-0,09$ & 0,51 & 0,41 \\
\hline S & - & - & 1 & 0,68 & 0,68 & 0,73 & 0,79 & $-0,61$ & $-0,96^{* *}$ \\
\hline FWS & - & - & - & 1 & $0,99 * *$ & $0,94 *$ & 0,68 & 0,08 & $-0,62$ \\
\hline DWS & - & - & - & - & 1 & $0,94^{*}$ & 0,68 & 0,08 & $-0,62$ \\
\hline \multicolumn{10}{|c|}{ Ammonium sulphate } \\
\hline $\mathrm{Ca}$ & 1 & $-0,44$ & $-0,92 *$ & 0,11 & 0,11 & 0,38 & 0,38 & 0,68 & 0,36 \\
\hline S & - & 0,41 & 1 & 0,01 & 0,01 & $-0,51$ & $-0,51$ & $-0,90 *$ & $-0,27$ \\
\hline FWS & - & $-0,01$ & - & 1 & $0,99 * *$ & 0,40 & 0,41 & 0,01 & 0,54 \\
\hline \multicolumn{10}{|c|}{ Inoculant (Bradyrhizobium elkanii) } \\
\hline $\mathrm{N}$ & 0,41 & 0,48 & 0,71 & $-0,98 * *$ & $-0,98 * *$ & $-0,44$ & $-0,80$ & $-0,50$ & $-0,61$ \\
\hline $\mathrm{Mg}$ & 0,86 & 1 & $0,88^{*}$ & $-0,61$ & $-0,61$ & 0,10 & $-0,63$ & $-0,30$ & $-0,31$ \\
\hline $\mathrm{S}$ & 0,73 & - & 1 & $-0,81$ & $-0,81$ & $-0,29$ & $-0,91 *$ & $-0,67$ & $-0,56$ \\
\hline FWS & $-0,50$ & - & - & 1 & $0,99 * *$ & 0,37 & 0,85 & 0,53 & 0,64 \\
\hline \multicolumn{10}{|c|}{ Control } \\
\hline $\mathrm{N}$ & 0,11 & $-0,58$ & $-0,02$ & 0,01 & 0,01 & 0,59 & 0,80 & $-0,92^{*}$ & 0,23 \\
\hline $\mathrm{K}$ & $-0,90^{*}$ & 0,73 & 0,47 & 0,78 & 0,78 & 0,64 & $-0,21$ & 0,27 & 0,08 \\
\hline $\mathrm{Ca}$ & 1 & $-0,44$ & $-0,05$ & $-0,94 *$ & $-0,94 *$ & $-0,45$ & $-0,07$ & $-0,17$ & $-0,30$ \\
\hline FWS & - & 0,23 & $-0,14$ & 1 & $0,99 * *$ & 0,42 & 0,19 & 0,13 & 0,56 \\
\hline
\end{tabular}

$*$ significant at $5 \%$ probability by $\mathrm{T}$ test; $* *$ significant at $1 \%$ probability by $\mathrm{T}$ test

\section{CONCLUSIONS}

Urea and ammonium sulphate promote accumulation of macronutrients in leaves and the development of cowpea.
Ammonium sulphate increases yield of beans and pods, and it is a viable nitrogen and sulfur source for cowpea production in the Amazon region.

The nodulation with Bradyrhizobium elkanii wasn't efficient to replace the fertilization with nitrogen fertilizers for cowpea BRS Guariba.

RESUMO: O feijão-caupi é uma das principais alternativas alimentares para as populações das regiões norte e nordeste do Brasil, sendo consumido na forma de grãos verdes ou maduros. Apesar da importância social e da origem tropical, a espécie apresenta baixa produtividade na região amazônica, incluindo o estado de Roraima, devido à baixa qualidade agronômica e manejo incorreto do solo. O objetivo do trabalho foi caracterizar o desenvolvimento da cultura do feijão-de-corda com duas diferentes fontes de nitrogênio $(\mathrm{N})$ tratadas com inoculante. $\mathrm{O}$ experimento foi realizado no município de Rorainópolis (RR). O delineamento foi em blocos casualizados, com quatro tratamentos e cinco repetições. Foi utilizada a cultivar de feijão-caupi 'BRS Guariba'. Os tratamentos foram: testemunha (ausência de adubação nitrogenada), inoculante Bradyrhizobium elkanii, $60 \mathrm{~kg} \mathrm{ha}^{-1} \mathrm{de} \mathrm{N}$ provenientes da uréia e $60 \mathrm{~kg}^{-1}$ de $\mathrm{N}$ da fonte sulfato de amônio. Foram avaliados os teores foliares de macronutientes (N, P, K, Ca, Mg e S), peso da massa verde e seca da parte aérea, número de grãos secos por planta, produção de vagens e produção de grãos. Em relação ao acúmulo de nutrientes a uréia e sulfato de amônio foram as fontes que apresentaram desempenho superior. Em relação as 
características produtivas, o sulfato de amônio foi o que mais se destacou, sendo uma fonte viável de suprimento de $\mathrm{N}$ para o feijão-caupi na região amazônica. A nodulação com Bradyrhizobium elkanii não foi eficiente para substituir a adubação com fertilizantes nitrogenados para o feijão-caupi BRS Guariba.

PALAVRAS-CHAVE: Adubação. Bradyrhizobium elkanii. Vigna unguiculata.

\section{REFERENCES}

ALI, S. F.; RAWAT, L. S.; MEGHVANSI, M. K.; MAHNA, S. K. Selection of stress-tolerant rhizobial isolates of wild legumes growing in dry regions of Rajasthan, India. Journal of Agricultural and Biological Science, v. 4, p. 13-18, 2009.

AMBROSANO, E. J.; TANAKA, R. T.; MASCARENHAS, H. A. A.; RAIJ, B. van; QUAGGIO, J. A.; CANTARELLA, H. Leguminosas e oleaginosas. In: RAIJ, B. van; CANTARELA, H.; QUAGGIO, J. A.; FURLANI, A. M. C. (Ed.). Recomendações de adubação e calagem para o Estado de São Paulo. 2.ed. rev. Campinas: IAC, 1997. p. 189-203.

BRITO, M. M. P.; MURAOKA, T.; SILVA, E. C. Contribuição da fixação biológica de nitrogênio, fertilizante nitrogenado e nitrogênio do solo no desenvolvimento de feijão e caupi. Bragantia. Instituto Agronômico da Agência Paulista de Tecnologia dos Agronegócios, Campinas, v. 70, n. 1, p. 206-215, 2011.

CHAGAS-JUNIOR, A. F.; RAHMEIER, W.; FIDELIS, R. R.; SANTOS, G. R.; CHAGAS, L. F. B. Eficiência agronômica de estirpes de rizóbio inoculadas em feijãocaupi no Cerrado, Gurupi-TO1. Revista Ciência Agronômica. Universidade Federal do Ceará, Fortaleza, v. 41, n. 4, p. 709-714, dez. 2010.

CONAB. Companhia Nacional de Abastecimento. Acompanhamento da safra Brasileira: grãos, quinto levantamento, fevereiro de 2016. available in: www.conab.gov.br. Access: 25 fev. 2016.

CRAWFORD, N. M.; KAHN, M. L.; LEUSTEK, T.; LONG, S. R. Nitrogen and sulphur. In: BUCHANAN, B.B.; GRUISSEM, W.; JONES, R. L. (Ed). Biochemistry and molecular biology of plants. Rockville: American Society of Plant Phusiologists, 2000. chap. 16, p. 786-849.

FERREIRA, D. F. Sisvar: a computer statistical analysis system. Ciência e Agrotecnologia. Univ. Fed. De Lavras, Lavras, v. 35, n. 6, p. 1039-1042. 2011.

FREIRE FILHO, F. R.; LIMA, J. A. A.; RIBEIRO, V. Q. Feijão-caupi: avanços tecnológicos: Embrapa Informação Tecnológica, Brasília, p. 191-210, 2005.

GONÇALVES, J. R. P.; FONTES, J. R. A.; DIAS, M. C.; ROCHA, M. M.; FREIRE FILHO, F. R. BRS Guariba - Nova Cultivar de Feijão-caupi para o Estado do Amazonas. Embrapa Amazônia Ocidental, Comunicado Técnico, 76, 2009.

GUALTER, R. M. R.; LEITE, L. F. C; ALCANTARA, R. M. C. M.; COSTA, D. B.; LIMA, S. S. Avaliação dos efeitos da inoculação de Feijão-caupi (Vigna unguiculata Walp) com Bradyrhizobium elkanii. Revista Brasileira de Agroecologia. Iniv. Fed. Do Rio Grande do Sul, v. 2, n. 2, p. 637 - 640, 2007.

HOROWITZ, N.; MEURER, E. J. Oxidação do enxofre elementar em solos tropicais. Ciência Rural. Univ. Fed. De Santa Maria, Santa Maria, v. 36, p. 822-828, 2006. https://doi.org/10.1590/S0103-84782006000300015

HUNGRIA, M.; CAMPO, R. J.; MENDES, I. C. Fixação biológica do nitrogênio na cultura da soja. Londrina: Embrapa Soja. Circular técnica, n. 35. 2001. 48p. https://doi.org/10.1016/S0378-4290(99)00084-2

HUNGRIA, M.; VARGAS, M. A. T. Environmental factors affecting N2 fixation in grain legumes in the tropics, with an emphasis on Brazil. Field Crops Research, v. 65, p. 151-164, 2000. 
MALAVOLTA, E.; MORAES, M. F. Fundamentos do nitrogênio e do enxofre na nutrição mineral das plantas cultivadas. In: YAMADA, T.; ABDALLA, S. R. S.; TITTI, G. C. (Org). Nitrogênio e enxofre na agricultura brasileira. Piracicaba: IPNI, 2007. p. 189-238.

MALAVOLTA, E.; VITTI, G. C.; OLIVEIRA, S. A. (Ed.). Avaliação do estado nutricional de plantas: princípios e aplicações. 2.ed. Piracicaba: Potafós, 1997. 319p.

MARINHO, R. C. N.; NÓBREGA, R. S. A.; ZILLI, J. E.; XAVIER, G. R.; CARLOS ANTÔNIO FERNANDES SANTOS; AIDAR, S. T.; MARTINS, L. M. V.; FERNANDES JÚNIOR, P. I. Field performance of new cowpea cultivars inoculated with efficient nitrogen-fixing rhizobial strains in the Brazilian Semiarid. Pesquisa Agropecuária Brasileira, Brasília, v. 49, n. 5, p. 395-402, 2014.

https://doi.org/10.1590/S0100-204X2014000500009

NETO, J. D.; SANTOS, M. A. dos; SOARES, A. C.; NETO, F. da C. M.; SOUZA, C. M. de. Avaliação do sistema radicular e eficiência nutricional de cálcio e magnésio em mudas de Coffea arabica e Coffea canephora. Revista Verde, v. 9 , n. 3 , p. 307 - 312, 2014.

NEVES, M. C. P.; RUMJANEK, N. G. Diversity and adaptability of soybean and cowpea rhizobia in tropical soils. Soil Biology and Biochemistry, v. 29, n. 5/6, p. 889-895, 1997. https://doi.org/10.1016/S00380717(96)00205-2

NEVES, O. S. C.; CARVALHO, J. G. de; FERREIRA, E. V. de O.; ASSIS, R. P. de. Nutrição mineral, crescimento e níveis críticos foliares de cálcio e magnésio em mudas de umbuzeiro, em função da calagem. Revista Ceres, Viçosa, v. 55, n. 6, p. 575-583, 2008.

NOVAIS, R. F.; VENEGAS, V. H. A.; BARROS, N. F.; FONTES, R. L. F.; CANTARUTTI, R. B.; NEVES, J. C. L. (Ed.) Fertilidade do Solo. Viçosa: SBCS, 2007. 1017p.

PANAULLAH, G. M.; TIMSINA, J.; SALEQUE, M. A.; ISHAQUE, M.; PATHAN, A. B. M. B. U.; CONNOR, D. J.; SAHA, P. K.; QUAYYUM, M. A.; HUMPHREYS, E.; MEISNER, C. A. Nutrient uptake and apparent balances for rice-wheat sequences. III. Potassium. Journal of Plant Nutrition, v. 29, p. 173-187, 2006. https://doi.org/10.1080/01904160500416554

PEGORARO, R. F.; OLIVEIRA, D.; MOREIRA, C. G.; KONDO, M. K.; PORTUGAL, A. F. Partição de biomassa e absorção de nutrientes pelo feijoeiro comum. Revista Caatinga, Mossoró, v. 27, n. 3, p. 41 - 52, 2014.

RAZA, S.; JORNSGARD, B.; ABOU-TALEB, H.; CHRISTIANSEN, J. L. Tolerance of Bradyrhizobium sp. (Lupini) strains to salinity, $\mathrm{pH}, \mathrm{CaCO} 3$ and antibiotics. The Society for Applied Microbiology, Letters in Applied Microbiology, v. 32, p. 379-383, 2001. https://doi.org/10.1046/j.1472-765X.2001.00925.x

RODRIGUES, C. S.; LARANJO, M.; OLIVEIRA, S. Effect of heat and pH stress in the growth of chickpea mesorhizobia. Current Microbiology, v. 53, p. 1-7, 2006. https://doi.org/10.1007/s00284-005-4515-8

RODRIGUES, G. B.; SÁ, M. E. de; VALÉRIO FILHO, W. V.; BUZETTI, S. BERTOLIN, D. C.; PINA, T. P. Matéria e nutrientes da parte aérea de adubos verdes em cultivos exclusivo e consorciado. Revista Ceres, Viçosa, v. 59, n. 3, p. 380-385, 2012.

SILVA JÚNIOR, E. B.; SILVA, K.; OLIVEIRA, S. S.; OLIVEIRA, P. J.; BODDEY, R. M.; ZILLI, J. E.; XAVIER, G. R. Nodulação e produção de feijão caupi em resposta à inoculação com diferentes densidades rizobianas. Pesquisa Agropecuária Brasileira, Brasília, v. 49, n. 10, p. 804-812, out. 2014. https://doi.org/10.1590/S0100-204X2014001000007 
SOUZA, M. D. M.; CARVALHO, C. M.; SABINO, R. K.; LOPES, P. H.; ALCÂNTARA, V. S.; SILVESTRE, A. C. A. Efeito da adubação potássica no crescimento do feijão de corda preto. Rev. Bras. Agric. Irrigada. Fortaleza, v. 7, n. 1, p. $66-73$.

TAGLIAFERRE, C.; SANTOS, T. J.; SANTOS, L. da C.; SANTOS NETO, I. J. dos; ROCHA, F. A.; PAULA, A. de. Características agronômicas do feijão-caupi inoculado em função de lâminas de irrigação e de níveis de nitrogênio. Revista Ceres, Viçosa, v. 60, n. 2, p. 242-248, 2013.

VALE JÚNIOR , J. F.; SOUZA, M. I. L.; NASCIMENTO, P. P. R. R.; CRUZ, D. L .S. Solos da Amazônia: etnopedologia e desenvolvimento sustentável. Revista Agro@mbiente On-line, Roraima, v. 5, n. 2, p.158165, agos, 2011.

VIANA, E. M.; KIEHL, J. C. Doses de nitrogênio e potássio no crescimento do trigo. Bragantia, Campinas, v. 69, n. 4, p. 975-982, 2010.

XAVIER, T. F.; ARAÚJO, A. S. F.; SANTOS, V. B.; CAMPOS, F. L. Inoculação e adubação nitrogenada sobre a nodulação e a produtividade de grãos de feijão-caupi. Ciência Rural, Santa Maria, v. 38, n. 7, p. 2037 2041, 2008. https://doi.org/10.1590/S0103-84782008000700038

ZILLI, J. E.; VILARINHO, A. A.; ALVES, J. M. A. A Cultura do Feijão - Caupi na Amazônia Brasileira. Embrapa Roraima, RR, 356 p. 2009.

ZILLI, J. E.; VALICHESKI, R. R.; RUMJANEK, N .G.; SIMÕES-ARAÚJO, J. L.; FREIRE FILHO, F. R.; NEVES, M. C. P. Eficiência simbiótica de estirpes de Bradyrhizobium isoladas de solo do cerrado em feijãocaupi. Pesquisa Agropecuária Brasileira, Brasília, v. 41, n. 5, p. 811-818, 2006.

https://doi.org/10.1590/S0100-204X2006000500013 